\title{
Pengembangan Model Evaluasi Pembelajaran Daring di Sekolah Menengah Kejuruan
}

\author{
Muttaqin Kholis Ali ${ }^{1}$, Sukardi Sukardi ${ }^{1}$ \\ ${ }^{1}$ Program Studi Pendidikan Teknologi dan Kejuruan, Fakultas Teknik, Universitas Negeri Padang, Indonesia
}

\begin{tabular}{l} 
Article Info \\
\hline Article history: \\
Received May $8^{\text {th }}, 2021$ \\
Revised Jun $19^{\text {th }}, 2021$ \\
Accepted Jul $22^{\text {th }}, 2021$ \\
\hline
\end{tabular}

\section{Keyword:}

Evaluasi

Pembelajaran

Daring

\begin{abstract}
Penelitian ini bertujuan untuk mengembangkan media evaluasi pembelajaran daring yang efektif dan memudahkan guru dalam penilaian. Metode penelitian yang digunakan adalah Penelitian dan Pengembangan (Research and Development) berdasarkan teori Borg dan Gall. Model ini meliputi 5 tahap. Subjek uji coba dalam penelitian ini adalah orang-orang yang terlibat dalam pelaksanaan pembelajaran daring di SMK Harapan Bangsa Panti Pasaman populasi penelitian berjumlah 25 orang. Hasil penelitian yang diperoleh yaitu: Media Evaluasi pembelajaran daring mata pelajaran Administrasi Infrastruktur Jaringan; Media Evaluasi pembelajaran daring yang valid dengan nilai 0,88 >0,05; Media Evaluasi pembelajaran daring yang sangat praktis berdasarkan respon guru dengan persentase 87,71\%; Media Evaluasi pembelajaran daring yang dinyatakan efektif dapat terlihat dari respon guru dan peserta didik dengan persentase 82,09.
\end{abstract}

C 2021The Authors. Published by IICET.

This is an open access article under the CC BY-NC-SA license

(https://creativecommons.org/licenses/by-nc-sa/4.0)

\section{Corresponding Author:}

Ali, M. K.,

Program Studi Pendidikan Teknologi dan Kejuruan, Fakultas Teknik, Universitas Negeri Padang, Indonesia Email: muttaqinkholis51@gmail.com

\section{Pendahuluan}

Pendidikan merupakan usaha sadar dan terencana untuk mewujudkan suasana proses pembelajaran agar peserta didik secara aktif dan kreatif dapat mengembangkan potensi dirinya: spiritual keagamaan, pengendalian diri, kepribadian, kecerdasan, akhlak mulia, serta keterampilam yang diperlukan dirinya (UU No. 20 tahun 2003). Sumber daya yang berkualitas ini sangat diperlukan oleh peserta didik dalam menghadapi arus globalisasi yang terjadi yaitu Dalam era society 5.0 masyarakat dihadapkan dengan teknologi yang memunkinkan pengaksesan dalam ruang maya yang terasa seperti ruang fisik. Dalam teknologi society 5.0 AI berbasis big data dan robot untuk melakukan atau mendukung pekerjaan manusia. Sehingga (Faulinda dan Aghni, 2020), hal tersebut menjadi tantangan bagi sekolah dalam menghasilkan lulusan dengan berbagai keunggulan yang kompetitif. Akan tetapi, institusi Pendidikan saat ini sedang menghadapi cobaan yang cukup berat.

Saat ini dunia dikejutkan dengan adanya wabah virus COVID-19 (Corona Virus Diseases-19) pada tanggal 31 desember 2019 di Kota Wuhan Provinsi Hubei Tiongkok, yang saat ini telah melanda hampir ke seluruh dunia, WHO menetapkan hal ini sebagai pandemi global. COVID-19 ini menyebar dengan sangat cepat hingga sampai ke Indonesia, maka Indonesia dan dunia dituntut untuk mempersiapkan diri untuk menghadapi virus ini (Aji, 2020). Pandemi ini sudah mempengaruhi semua sektor yang ada di masyarakat, termasuk sektor Pendidikan, sehingga telah menyebabkan terjadinya krisispada Pendidikan (Basilaia \& 
Kvavadze, 2020) yang tidak dipersiapkan oleh siapa pun. Penutupan sekolah di seluruh dunia telah memengaruhi jutaan siswa yang dampaknya belum diketahui (Zhang et al., 2020; Judd et al., 2020).

Mewabahnya COVID-19 telah memberikan tantangan tersendiri bagi semua elemen Pendidikan, isntitusi Pendidikan (sekolah dan Pendidikan tinggi), pendidik, peserta didik bahkan orang tua (Herliandy dkk., 2020), Untuk mengantisipasi penyebaran virus tersebut pemerintah mengeluarkan kebijakan seperti social distancing, physical distancing, sehingga sosial berskala besar (PSBB). pelaksanaan pembelajaran daring guru juga dituntut untuk lebih inovatif dalam penyusun Langkah-langkah pembelajaran, agar perubahan cara belajar ini dapat membuat guru dan siswa beradaptasi lebih cepat dari pembelajaran tatap muka dikelas menjadi pembelajaran daring (Mastuti, et al., 2020).

Secara teknis dalam pembelajaran daring perangkat pendukung seperti komputer atau laptop, smartphone atau alat bantu lainnya yang bisa terhubung ke koneksi internetharus tersedia untuk kedua belah pihak pengajar dan siswa (Winarno, 2017; Bourne, Harris\& Mayadas, 2005). Dengan bantuan perangkat pendukung tersebut dapat memudahkan guru dalam menyiapkan media pembelajaran dan menyusun Langkah-langkah pembelajaran yang akan diterapkan sehingga siswa menjadi termotivasi untuk belajar dan hasil belajarnya tercapai. Akan tetapi, meskipun guru telah berusahan memaksimalkan penggunaan media pada pembelajaran daring, guru juga masih kesulitan dan kendala ketika pelaksanaan pembalajaran daring. Hal terseebut dibuktikan ketika peneliti melakukan observasi di SMK Harapan Bangsa, dimana terdapat tiga aspek yang peneliti observasi, yaitu dari segi persiapan pembelajaran, pelaksanaan pembelajaran dan evaluasi pembelajaran.

Segi persiapan pembelajaran guru merasa terbatas dalam mempersiapkan quality lesson plan untuk mengatur langkah-langkah pembelajaran dengan detail, karena guru juga harus mendapingi anaknya untuk melajar dirumah sehingga persiapan pembelajaran pun menjadi tidak maksimal. Serta guru mengalami kesulitan untuk memilih metode pembelajaran yang menyenangkan dan memilih tugas, karena terdapat beberapa siswa yang tidak mengumpulkan tugas dan tidak mengikuti pembelajaran. segi pelaksanaan pembelajaran bahwa terdapat banyak keluhan dari siswa dan orang tua siswa terhadap proses pembelajaran daring, seperti siswa malas belajar dan lebih banyak bermain, kurangnya semangat anak untuk belajar, sisi evaluasi pembelajaran, guru mempunyai kendala dalam mengevaluasi pembelajaran dan tugas siswa, karena tidak disiplinnya siswa dalam mengikuti pembelajaran daring dan mengumpulkan tugas, sehingga guru menjadi bingung dalam mengisi nilai siswa.

Pendidikan kejuruan adalah pendidikan yang mempersiapkan orang untuk bekerja sebagai teknisi atau untuk mengambil pekerjaan di bidang kerajinan atau perdagangan terampil sebagai pedagang atau pengrajin. Pendidikan kejuruan terkadang disebut sebagai pendidikan karir dan teknik (Avis, 2014). "Sekolah kejuruan adalah jenis lembaga pendidikan yang dirancang khusus untuk menyelenggarakan pendidikan vokasi. Laporan Pembangunan Dunia oleh World Bank (2019) tentang masa depan pekerjaan menunjukkan bahwa fleksibilitas antara pendidikan umum dan vokasi terutama di pendidikan tinggi sangat penting untuk memungkinkan pekerja bersaing dalam pasar tenaga kerja yang terus berubah di mana teknologi memainkan peran yang semakin penting". Di bawah ini adalah serangkaian karakteristik kunci dari sistem vokasi. karakteristik ini didasarkan pada rekomendasi kebijakan untuk pendidikan kejuruan dan pelatihan lanjutan dalam laporan OECD (2010), yaitu sebagai berikut: 1. Menyediakan dan memenuhi kebutuhan: Bagaimana campuran dan konten program kejuruan ditentukan; 2. Memberikan kualitas: Bagaimana keterampilan kejuruan ditanamkan kepada peserta didik; 3. Menggunakan hasil pembelajaran: Bagaimana keterampilan dinilai, disertifikasi dan dieksploitasi; 4. Kondisi pendukung: Kebijakan, praktik, dan lembaga yang mendukung pendidikan dan pelatihan kejuruan.

Pembelajaran daring adalah pendidikan yang berlangsung melalui Internet. Ini sering disebut sebagai " $e$ learning" di antara istilah lainnya(Arzayeva, Rakhimzhanov, Abdrahmanova \& Umitkaliev, 2015). Namun, pembelajaran daring hanyalah salah satu jenis "pembelajaran jarak jauh" - istilah umum untuk pembelajaran apa pun yang terjadi secara jarak jauh dan tidak di ruang kelas tradisional(Garrison \& Cleveland-Innes, 2005). Pembelajaran daring memenuhi kebutuhan populasi siswa yang terus bertambah yang tidak dapat atau memilih untuk tidak berpartisipasi dalam pengaturan ruang kelas tradisional (Korucu \& Alkan, 2011). Implementasi sistem pembelajaran daring di Indonesia yang telah berlangsung selama satu tahun, membawa berbagai perubahan dan dampak baik positif maupun negatif dalam proses belajar-mengajar (Simamora, 2020).

Pembelajaran daring menyediakan metode yang sangat baik untuk penyampaian pembelajaran yang tidak terikat oleh waktu atau lokasi yang memungkinkan aksesibilitas ke pengajaran kapan saja dari mana saja (Milman, 2015). Pelajar menemukan lingkungan online sebagai cara yang nyaman untuk menyesuaikan pendidikan ke dalam kehidupan mereka yang sibuk. Kemampuan untuk mengakses pembelajaran dari 
komputer atau smartphone dimana pun dengan akses Internet, 24 jam sehari, tujuh hari seminggu adalah insentif yang luar biasa bagi banyak siswa saat ini (Moore, Dickson \& Galyen, 2011).

Evaluasi memiliki makna yang berbeda dengan penilaian, pengukuran maupun tes. Arikunto (2004:1) Evaluasi adalah kegiatan untuk mengumpulkan informasi tentang bekerjanya sesuatu, yang selanjutnya informasi tersebut digunakan untuk menentukan alternatif yang tepat dalam mengambil sebuah keputusan. Menurut Ralph Tyler dalam Arikunto (2010), menyatakan bahwa evaluasi pembelajaran adalah proses untuk mengetahui apakah tujuan pendidikan sudah dapat terlealisasikan. Evaluasi pembelajaran adalah upaya menyediakan informasi untuk disampaikan kepada pengambil keputusan (Stufflebeam, 1971; Arikunto, 2014:5). Sehubungan dengan definisi tersebut The Standford Evaluation Consorsium Group menegaskan bahwa meskipun evaluator menyediakan informasi, evaluator bukanlah pengambil keputusan tentang suatu pembelajaran (Cronbach dalam Arikunto, 2014).

Arikunto dan Safruddin (2009) menyatakan bahwa tujuan evaluasi berkaitan dengan evaluator untuk mengetahui pencapaian tujuan pembelajaran dengan langkah mengetahui keterlaksanaan pembelajaran, karena evaluator ingin mengetahui alasan dan penyebab komponen dan sub komponen pembelajaran jika ada yang belum terlaksana". Beberapa tujuan evaluasi dan monitoring adalah sebagai berikut: 1) Menentukan tingkat kinerja suatu pembelajaran. (Untuk mengetahui derajat pencapaian tujuan dan sasaran); 2) Mengukur tingkat efisiensi suatu pembelajaran. (Untuk mengetahui berapa biaya dan manfaat dari suatu pembelajaran); 3) Mengukur tingkat keluaran (outcome) suatu pembelajaran. (Untuk mengukur besaran dan kualitas pengeluaran atau output dari pembelajaran); 4) Mengukur dampak suatu pembelajaran. (Untuk mengetahui dampak dari suatu pembelajaran, baik dampak Positif maupun negatif); 5) Untuk mengetahui apabila ada penyimpangan. 6) Sebagai bahan masukan (input) untuk pembelajaranyang akan dating (Grammatikopoulos, Hassandra, Koustelios \& Theodorakis, 2005).

Tujuan penelitian evaluasi pembelajaranadalah untuk mengukur dampak pembelajaranterhadap tujuantujuan yang ditetapkan, sebagai sarana memberikan kontribusi bagi pengambilan keputusan tentang pembelajarandan meningkatkan pembelajarandimasa depan (Stufflebeam dan Shinkfield, 1985). Dilihat dari tujuannya, evaluasi pembelajaran adalah untuk memperoleh informasi yang akurat dan objektif tentang pencapaian tujuan suatu pembelajaran dengan langkah mengetahui keterlaksanaan kegiatan pembelajaran, karena evaluator pembelajaran ingin mengetahui bagaimana komponen dan sub komponen yang belum terlaksana dan apa sebabnya (Irawati \& Jonathan, 2020).

\section{Metode}

Jenis penelitian yang digunakan adalah penelitian pengembangan (research and development). Penelitian pengembangan adalah penelitian yang digunakan untuk menghasilkan produk tertentu dan menguji keefektifan produk tersebut (Sugiyono, 2011). Model pengembangan dalam penelitian ini merujuk pada model Research and Development penelitian dan pengembangan) yang berdasarkan pada teori Borg dan Gall (2003) karena model pengembangan tersebut mempunyai prosedur yang lengkap, jelas dan sistematis, sesuai dengan masalah yang melatar belakangi penelitian ini. Subjek uji coba dalam penelitian ini adalah orang-orang yang terlibat dalam pelaksanaan pembelajaran daring di SMK Harapan Bangsa Panti Pasaman. populasi penelitian berjumlah 25 orang. Jika populasi kurang dari 100 objek maka diambil seluruh dari populasi sebagai sampel penelitian". Dengan demikian, teknik sampling yang digunakan disebut dengan Total Sampling (Arikunto, 2002).

Pada model Borg dan Gall ini terdapat 10 langkah pengembangan, namun pada penelitian ini penerapan prosedur penelitian pengembangan $(\mathrm{R} \& \mathrm{D})$ menunjukkan tidak semua langkah-langkah pada Borg and Gall dapat peneliti lakukan, karena beberapa alasan yang sesuai dengan kebutuahan dalam pengembangan yang dilakukkan, seperti penyederhanaan langkah-langkah penelitian yang dilakukan oleh Pusat Penelitian Kebijakan dan Inovasi (Puslitjaknov, 2008:11) menjadi lima (5) tahapan, yaitu: (a) Melakukan analisis terhadap produk yang akan dikembangkan; (b) pengembangan terhadap produk awal; (c) validasi oleh ahli dan kemudian revisi; (d) uji coba lapangan pada skala kecil dan revisi produk; (e) uji coba lapangan pada skala besar dan produk akhir.

Penilitian dilakukan di SMK Harapan Bangsa Panti Pasaman dengan sampel sebanyak 23 siswa dan 2 orang guru yang sedangan dalam proses belajar mengajar pada mata pelajaran Administrasi Infrastruktur Jaringan. Instrumen penelitian yang digunakan media evaluasi pembelajaran aring yang akan digunakan oleh siswa dan guru setelah itu siswa dan guru diberikan angket untuk mengisi kuisioner tentang efektivitas media pembelajaran yang digunaka. 


\section{Hasil dan Pembahasan}

Aplikasi ini dapat menampilkan soal ujian untuk siswa dan evaluasi pembelajaran yang akan diinput oleh guru sesuai dengan materi pelajaran administrasi infrastruktur jaringan. Hal ini sesuai untuk digunakan dalam pembuatan media evaluasi pembelajaran daring, selain dengan menampilkan soal ujian untuk siswa, media evaluasi pembelajaran daring juga dilengkapi dengan pengolahan nilai yang terdiri dari ranah kognitif, afektif dan psikomotor, Tampilan dari media dirancang seefektif mungkin agar guru dapat mudah memahami dan efektif dalam mengevaluasi pembelajaran dimasa pandei seperti sekarang.

Prototype merupakan rancangan awal dari sebuah aplikasi media evaluasi pembelajaran daring ini. Rancangan prototype dibuat sebelum melakukan validasi dan penelitian ke lapangan. Penyusunan kerangka media evaluasi pembelajaran daring dilakukan pada perancangan prototype yang menggambarkan desain dari media. Desain tampilan media evaluasi pembelajaran daring ini meliputi tampilan Dashboard guru, Dashboard siswa, halaman masuk, penilaian pengetahuan dan keterampilan oleh guru, evaluasi pembelajaran, penilaian keterampilan dan sikap siswa.

Data uji praktikalitas diperoleh dari pengisian angket kepraktisan media evaluasi pembelajaran daring oleh responden. Responden yang menilai media evaluasi pembelajaran daring adalah guru dan siswa pada mata pelajaran administrasi infrastruktur jaringan yang telah menggunakan media evaluasi pembelajaran daring dalam proses evaluasi. Respon Guru Terhadap Kepraktisan Media Evaluasi Pembelajaran Daring Tingkat kepraktikan media evaluasi pembelajaran daring yang digunakan dapatdiperoleh melalui instrumen angket yang diisi oleh praktisi. Praktisi inimerupakan guru mata pelajaran Administrasi Infrastruktur Jaringan yang telah menggunakana media evaluasi pembelajaran daring. Data praktikalitas dianalisis agar diketahui kesimpulan terkait tingkat kepraktisan dari media evaluasi pembelajaran daring yang dikembangkan. Berikut merupakan hasil penilaian praktikalitas oleh guru disajikan pada Tabel 1.

Tabel $1<$ Hasil Analisis Data Praktikalitas Media Evaluasi Pembelajaran Daring>

\begin{tabular}{lccccc}
\hline \multirow{2}{*}{ No } & Aspek & \multicolumn{2}{c}{ Persentase Penilaian } & & Kategori \\
& Penilaian & P1 & P2 & Rata2 & \\
1 & Teknis & $88,00 \%$ & $84,00 \%$ & $86,00 \%$ & Sangat Praktis \\
2 & Isi & $88,00 \%$ & $92,00 \%$ & $90,00 \%$ & Sangat Praktis \\
3 & Desain & $88,57 \%$ & $85,71 \%$ & $87,14 \%$ & Sangat Praktis \\
\multicolumn{2}{l}{ Rata-Rata } & & & $\mathbf{8 7 , 7 1 \%}$ & Sangat Praktis \\
\hline
\end{tabular}

Berdasarkan Tabel 1 terlihat hasil analisis data praktikalitas media evaluasi pembelajaran daring pada mata pelajaran Administrasi Infrastruktur Jaringan melalui respon guru didapatkan nilai praktikalitas sebesar $87,71 \%$ dengan kategori sangat praktis. Pada aspek teknis media evaluasi pembelajaran daring nilai persentase sebesar $86,00 \%$ dengan kategori sangat praktis. Pada aspek isi media evaluasi pembelajaran daring nilai persentase sebesar $90,00 \%$ dengan kategori sangat praktis. Pada aspek desain media evaluasi pembelajaran daring nilai persentase sebesar $87,14 \%$ dengan kategori sangat praktis.

Efektivitas Model evaluasi pembelajaran daring ditentukan dengan cara melihat pemberian angket efektivitas kepada guru dan siswa mengenai model evaluasi pembelajaran daring yang dikembangkan. Perhitungan efektivitas model evaluasi dapat dilakukan dengan menggunakan rumus Derajat Pencapaian (DP). Berdasarkan hasil uji normalitas yang telah dilakukan didapati nilai normalitasseperti pada Tabel 2.

Tabel $2<$ Nilai Presentasi dari Derajat Pencapaian (DP) $>$

\begin{tabular}{lcc}
\hline Kelas & Presentasi & Kategori \\
Derajar Pencapaian (DP) & $82,09 \%$ & Efektif \\
\hline
\end{tabular}

Berdasarkan Tabel 2 diketahui bahwa nilai presentasi dari derajat pencapaian (DP) media evaluasi pembelajaran daring sebesar 82,09\% dengan kategori Efektif.

\section{Simpulan}

Penelitian ini menghasilkan media Evaluasi Pembelajaran Daring di SMK Harapan Bangsa Panti. Uji validitas pada media Evaluasi Pembelajaran Daring dilakukan dengan, yaitu validitas media oleh para ahli. Validitas media Evaluasi Pembelajaran Daring yang dilakukan oleh 3 validator memperoleh nilai 0,88dengan kriteria "Valid". Media Evaluasi Pembelajaran Daring ini telah dilakukan uji praktikalitas oleh guru. Pada 
uji Praktikalitas diperoleh dari angket respon guru terhadap praktikalitas media Evaluasi Pembelajaran Daring pada mata pelajaran administrasi infrastruktur jaringan sebesar $87,71 \%$ dengan kategori "Sangat Praktis". Media Evaluasi Pembelajaran Daring ini telah dilakukan uji efektivitas pada guru dan siswa mata pelajaran administrasi infrastruktur jaringan. Pada uji efektivitas didapatkan hasil bahwa media Evaluasi Pembelajaran Daring pada mata pelajaran administrasi infrastruktur jaringan efektif untuk digunakan, hal ini dibuktikan dengan respon guru dan siswa pada pengisian angket yang diperoleh sebesar 82,09\% dengan kategori "Efektif".

Perkembangan teknologi memiliki pengaruh signifikan terhadap proses pengajaran dan pembelajaran dalam jaringan (daring) (Ass Aliana, 2020). Pembelajaran daring yang diberlakukan untuk mematuhi kebijakan pemerintah terkait physical distancing merupakan pelaksanaan proses belajar mengajar dengan memanfaatkan jaringan internet tanpa terbatas oleh ruang dan waktu (Dwinda dan Dadang, 2021). Pembelajaran daring memiliki dampak positif berupa kemandirian siswa dalam belajar, peningkatan aktivitas mencari sumber belajar dan inovasi gaya belajar. Adapun dampak negatif berupa penurunan intensitas siswa dalam belajar sebagai akumulasi dari rasa jenuh, kurang berinteraksi dengan teman sebaya dan gangguan pada jaringan atau media pembelajaran (Jumardi Budiman, 2021).

Pembelajaran daring juga menjadi tantangan bagi guru untuk mampu menyusun strategi pengajaran yang tepat untuk membangkitkan minat dan motivasi belajar siswa, memberikan pemahaman kepada siswa tentang pentingnya tetap belajar meskipun dari rumah, membuat materi pembelajaran yang singkat dan padat dengan menggunakan media pembelajaran yang menarik, serta melakukan evaluasi secara berkala dan berkesinambungan (Allo, 2020; Sutarto et al., 2020). Siswa juga tidak mampu memahami materi secara utuh karena terbatasnya komunikasi yang terjadi dengan guru selama pembelajaran daring (Irawan et al., 2020; Jariyah \& Tyastirin, 2020; Wijaya et al., 2020).

\section{Referensi}

Aas Aliana F, dkk. (2020). Efektivitas Pembelajaran Daring di Masa Pandemi Covid-19. Jurnal Penelitian Ilmu-Ilmu Sosial, 21(2), 53-56. http://sosial.unmermadiun.ac.id/index.php/sosial

Aji, R. H. S. (2020). Dampak Covid-19 pada Pendidikan di Indonesia: Sekolah, Keterampilan, dan Proses Pembelajaran. SALAM: Jurnal Sosial \& Budaya Syar'i. 7 (5), pp. 395-402.

Arikunto. 2014. Evaluasi Program Pendidikan. Jakarta: PT Bumi Aksara

Arikunto \& Safrudin. 2009. Evaluasi ProgramPendidikan. Jakarta: Bumi Aksara.

Arzayeva, M., Rakhimzhanov, K., Abdrahmanova, A., \& Umitkaliev, U. (2015). Special aspects of distance learning in educational system. Anthropologist, $449-454$. https://doi.org/10.1080/09720073.2015.11891900

Avis, J. 2014. "Workplace Learning, VET and Vocational Pedagogy: The Transformation of Practice." Research in Post-Compulsory Education 19 (1): 45-53. doi:10.1080/13596748.2014.872920.

Borg \& Gall,2003. Education Research. New York: Allyn and Bacon.

Dwinda Nur Baety dan Dadang Rahman M, (2021). Analasis Efektifitas Pembelajaran Daring Dalam Menghadapi Wabah Pandemi Covid-19, 3(3), 880-889. https://edukatif.org/index.php/edukatif/index

Faulinda Ely Nastiti dan Aghni Rizqi Ni'mal 'Abdu. (2020). Kesiapan Pendidikan Indonesia Menghadapi era society 5.0. Jurnal Kajian Teknologi Pendidikan. 5 (1) 61-66.

Garrison, D. R., \& Cleveland-Innes, M. (2005). in Online Learning : Interaction Is Not Enough. American Journal of Distance Education. https://doi.org/10.1207/s15389286ajde1903

Grammatikopoulos, V., Hassandra, M., Koustelios, A., \& Theodorakis, Y. (2005). Evaluating the Olympic education program: a qualitative approach. Studies in Educational Evaluation, 31(4), 347-357.

Herliandry, L. H., Nurhasanah, Suban, M.E. \& Kuswanto, H. (2020). Pembelejaran Pada Masa Pandemi COVID-19. Jurnal Teknologi Pendidikan. 22 (1), pp. 65-70.

Irawan, A. W., Dwisona, D., \& Lestari, M. (2020). Psychological Impacts of Students on Online Learning During the Pandemic COVID-19. KONSELI : Jurnal Bimbingan Dan Konseling (E-Journal), 7(1), 5360. https://doi.org/10.24042/kons.v7i1.6389

Irawati, D. Y. \& Jonathan. (2020). Evaluasi Kualitas Pembelajaran Online Selama Pandemi Covid-19: Studi Kasus di Fakultas Teknik, Universitas Katolik Darma Cendika. Jurnal Rekayasa Sistem Industri. 9 (2), pp. 135-144.

Jumardi Budiman, (2021). Evaluasi Pelaksanaan Pembelajaran Daring Di Indonesia Selama Masa Pandemi Covid-19. 12(1), 104-113. DOI: https://doi.org/10.31932/ve.v12i1.1074

Korucu, A. T., \& Alkan, A. (2011). Differences between m-learning (mobile learning) and elearning, basic terminology and usage of m-learning in education. Procedia - Social and Behavioral Sciences. https://doi.org/10.1016/j. sbspro.2011.04.029 
Mastuti, R. et al. (2020). Teaching From Home: Dari Belajar Merdeka menuju Merdeka Belajar. Medan: Yayasan Kita Menulis.

Milman, N. B. (2015). Distance Education. In International Encyclopedia of the Social \& Behavioral Sciences: Second Edition. https://doi.org/10.1016/B978-0-08- 097086-8.92001-4

Moore, J. L., Dickson-Deane, C., \& Galyen, K. (2011). E-Learning, online learning, and distance learning environments: Are they the same? Internet and Higher Education. https://doi.org/10.1016/jiheduc.2010.10.001

Puslitjaknov. 2008. "Metode Penelitian Pengembangan". Departemen Pendidikan Nasional.

Rohmawati, A. (2015). Efektivitas Pembelajaran. Jurnal Pendidikan Usia Dini, 9(1), 15-32.

Simamora, R. M. (2020). The Challenges of Online Learning during the COVID-19 Pandemic: An Essay Analysis of Performing Arts Education Students. Studies in Learning and Teaching, 1(2), 86-103. https://doi.org/10.46627/silet.v1i2.38

Stufflebeam, D. L. dan Shinkfield, A. J. 1985. Systematic Evaluation: A Self-Instructional Guide to Theory and Practice. Massachusetts: Kluwer-Nijhoff Publishing.

Sugiyono. 2011. Metode Penelitian Kuantitatif, Kualitatif dan R\&D. Bandung: Alfabeta

Winarno, W. (2017). Design and Implementation of Web-Based Lecture Evaluation System. Jurnal Pendidikan Islam UIN Sunan Gunung Djati, 3(2), 235-248.

Zhang, W. , Y.Wang, L.Yang, and C.Wang . 2020. "Suspending Classes without Stopping Learning: China's Education Emergency Management Policy in the COVID-10 Outbreak." Journal of Risk and Financial Management 13 (3): 1-6. doi:10.3390/jrfm13030055. 